\section{Soil bio-engineering for watershed management and disaster mitigation in Ecuador: a short-term species suitability test}

\author{
Federico Preti, Alessandro Petrone
}

This paper reports a soil bio-engineering technical assessment program conducted in the Santo Domingo, Ecuador region. Autochthonous plant species survivorship and vegetative growth was evaluated in a short-term palisade experimental regime. Among the four species evaluated, Brugmansia versicolor, Malvaviscus penduliflorus, and Trichanthera gigantea performed well, evidenced by $>70 \%$ survivorship, however Euphorbia cotinifolia exhibited increased mortality (59\%). Significant differences and notable variability in terminal shoot length and stem diameter among species indicated further study is warranted in growth parameters.

Keywords: Soil bio-engineering, Ecuador, Watershed Management, Disaster Mitigation

\section{Introduction}

Landslides, flooding, and erosion are among the most threatening natural hazards in tropical and sub-tropical countries (e.g. Petley et al. 2005, Miner \& Villagran de Leon 2008). Soil bio-engineering techniques are considered important tools to combat erosion, shallow land-slides, bank instability, desertification, and drought (Schiechtl \& Michaelsen 1985). Gray \& Sotir (1996) provided evidence these techniques contributed to soil strength, with positive influences on geotechnical, hydrological, and hydraulic soil characteristics. Lasting beneficial effects on soil physical and chemical properties were reported in other studies (e.g., Schwarz et al. 2006, Moscatelli et al. 2009, Preti et al. 2011). It is clear soil bio-engineering methods are a low cost, environmentally conscience, and effective solution for even large-scale erosion control, and riverbank and slope protection.

Soil bio-engineering has been implemented frequently in Europe (Evette et al. 2009), and has also been successful in developing countries, including Nepal (Florineth 2004, Ghimire \& Karki 2004, Lammeraner et al. 2005, Acharya \& Lammeranner 2011, Rauch et al. 2011), Brazil (Sutili et al. 2004), Colombia (Rivera \& Sinisterra 2006), Ethiopia (Reubens et al. 2007), and Nicaragua (Petrone \& Preti 2008, 2010).

Once soil bio-engineering techniques are defined, appropriate plant species selection is based on the following factors: (i) function plan (catch, armour, reinforce, anchor, and support or drain, among other components); (ii) site characteristics (physical environment, climate, soil type, moisture conditions); and (iii) regional economic and social criteria (e.g., Rossi Pisa et al. 1999, Reza Pezeshki et al. 2007, Preti \& Giadrossich 2009, Acharya \& Lammeranner 2011, Osman \& Barakbah 2011).

In the framework of the "Disaster Risk Reduction in Santo Domingo de los Tsáchilas" (EU-DIPECHO) project, the present study tested the suitability of autochthonous species, recommended by local residents and experts, to establish soil bio-engineering installations in Ecuador. Our project was characterized by a strong involvement of local communities, as we shared with local people the choice of the experimental site, soil bioengineering installations, and all monitoring procedures; we also trained people to soil bio-engineering techniques. We think this is vital because local people are one of the stakeholders, and this involvement makes it their project.
Ingegneria dei Biosistemi Agrari e Forestali, DEISTAF, University of Florence, I-50100 Florence (Italy)

@ Federico Preti (federico.preti@unifi.it)

Received: Aug 08, 2012 - Accepted: Oct 19, 2012

Citation: Preti F, Petrone A, 2013. Soil bioengineering for watershed management and disaster mitigation in Ecuador: a short-term species suitability test. iForest 6: 95-99 [online 2013-02-07] URL:

http://www.sisef.it/iforest/contents/? id $=$ ifor $0636-006$

Communicated by: Roberto Tognetti

Study area, experimental design, and monitoring procedures

The town of Santo Domingo is located in Santo Domingo de los Tsachilas Province (Fig. 1) in north-central Ecuador, at $655 \mathrm{~m}$ a.s.l. The climate is sub-tropical, air temperatures range from 18 to $26^{\circ} \mathrm{C}$, and annual precipitation is $4260 \mathrm{~mm}$, which peaks in January and April; $6.5 \%$ of the area is tropical forest, $62.9 \%$ pasture, and $30.9 \%$ cultivated lands. The region is prone to natural hazards, particularly landslides, which often cause human life casualties. Road interruption is common, complicating emergency medical and evacuation measures. Pastures are often on steep slopes, increasing the risk of massive erosive processes (Petrone \& Preti 2010).

Assessment of soil bio-engineering installations was conducted at several urban and rural area sites in Santo Domingo. Here we report the results obtained from the experimental site "San Miguel de Lelia" (lat. $0^{\circ} 20^{\prime} 08^{\prime}$ S, long. $79^{\circ} 00^{\prime} 05^{\prime}$ W, $870 \mathrm{~m}$ a.s.1.), which was chosen based on the local community's perception of the project uti-

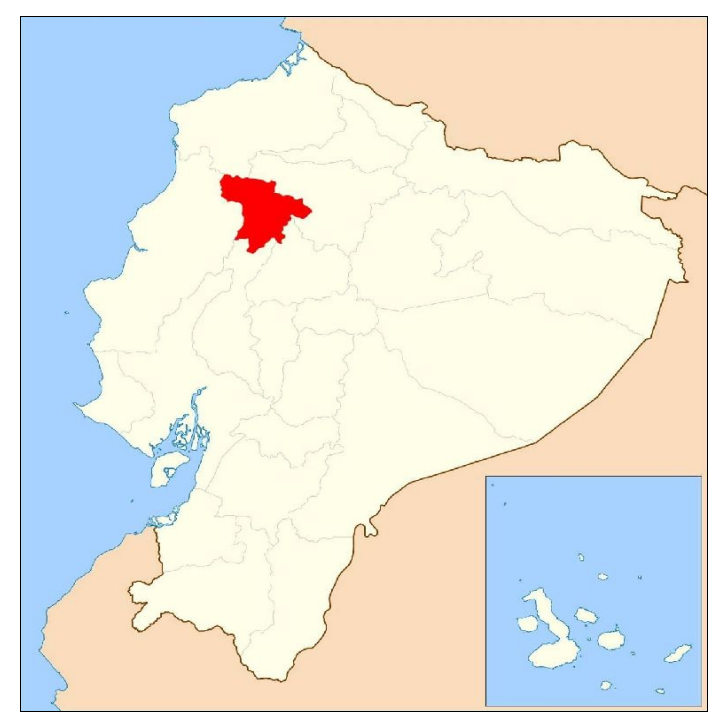

Fig. 1 - The Santo Domingo de los Tsáchilas Province in Ecuador. 


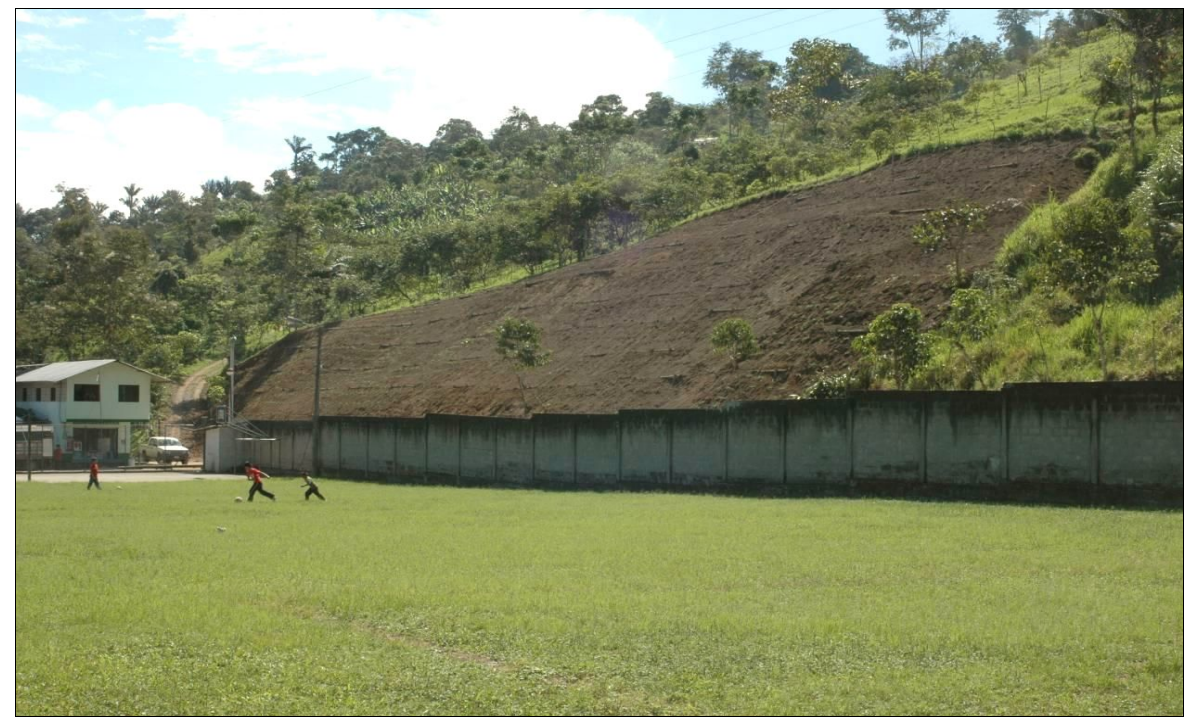

Fig. 2 - Live palisade following construction.

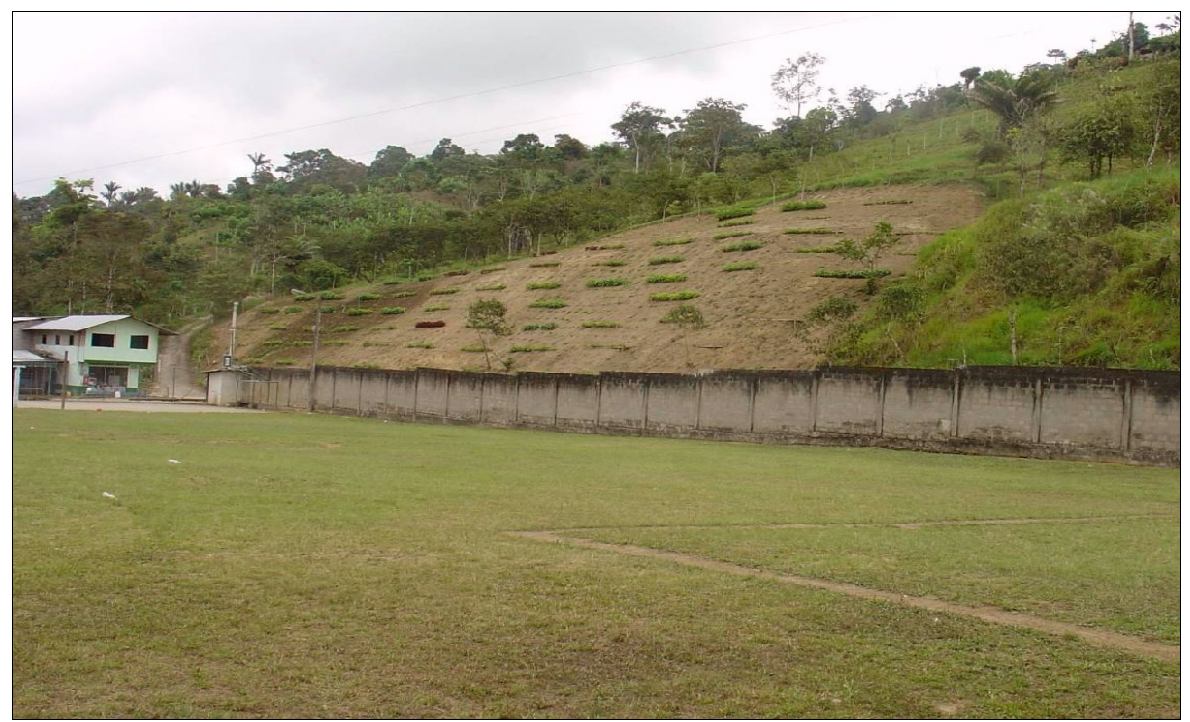

Fig. 3 - Live palisade two months following construction.

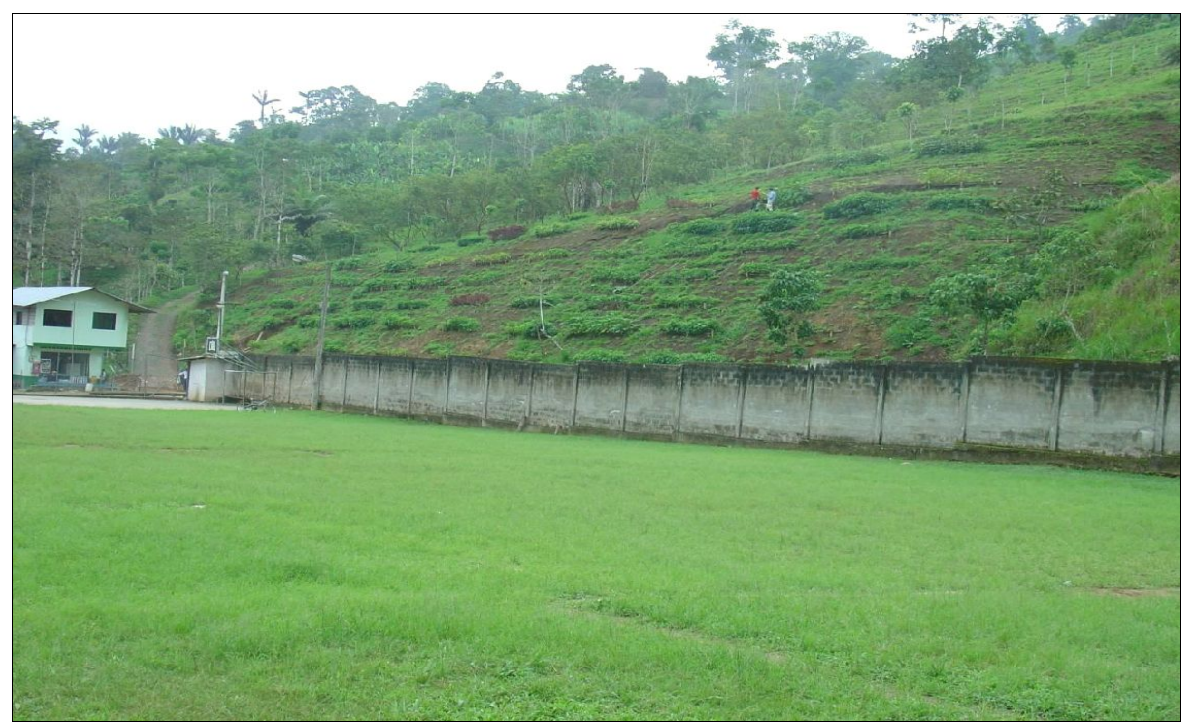

Fig. 4 - Live palisade five months following construction. lity, site accessibility, and on-going erosional processes.

The experimental area $(86 \times 26 \mathrm{~m})$ is located on an east-southeast facing re-profiled road slope (inclination: $36^{\circ}$ ), with high subsurface water availability. Soil is silty-clay sub-alkaline ( $\mathrm{pH} 6.1$ ) with low organic matter content $(1.1 \%), \mathrm{NH}_{4}=6.8 \mathrm{ppm}, \mathrm{P}=4.7$ ppm, and $\mathrm{K}=0.65 \mathrm{meq} / 100 \mathrm{~g}$ (Fig. 2, Fig. 3, Fig. 4).

We involved the local communities and experts to provide the following criteria to choose appropriate plant species for this bioengineering assessment (Petrone \& Preti 2005, Petrone \& Preti 2008): (i) autochthonous plant species, with high potential for propagation from stem cuttings; (ii) wide tolerance to variable soil conditions; and (iii) moderate size at maturity. Local people were also involved and properly trained for the experimental design, soil bio-engineering installation, and monitoring procedures. This activity took place in the framework of a cooperative agreement with the local institutions.

The following species were tested: Brugmansia versicolor Lagerh (Solanaceae, local common name: Guanto - Fig. 5); Euphorbia cotinifolia L. (Euphorbiaceae, local common name: Lechoso - Fig. 6); Malvaviscus penduliflorus DC. (Malvaceae, local common name: Cucarda - Fig. 7); and Trichanthera gigantea (Humb. \& Bonpl.) Nees (Acanthaceae, local common names: Nacedero, quiebrabarriga, inchabarriga - Fig. 8). All species have been used for many years by the local population.

Plant species performance was assessed in a live palisade experiment constructed with local bamboo (caña guadua), and grass transplants at the San Miguel de Lelia experimental site (Fig. 2, Fig. 3, Fig. 4). One hundred cuttings from each species were planted in July 2010, using standard planting techniques. Plant cuttings were collected in the immediate surroundings. Initial cutting length was the same $(60 \mathrm{~cm})$ for all species. Average stem diameter for each species was as follows: B. versicolor $27 \pm 9.27 \mathrm{~mm}$ (mean \pm standard deviation); E. cotinifolia $33 \pm 7.04 \mathrm{~mm}$; M. penduliflorus $19 \pm 5.06$ $\mathrm{mm}$ ); and T. gigantea $32 \pm 7.37 \mathrm{~mm}$. At three dates (August, September, and December 2010), the following traits were measured: survival rate (sprout percent from cuttings); terminal shoot length; and stem diameter at terminal shoot base. Terminal shoot length and stem diameter are considered important traits that correlate with root system development, and therefore reflect plant capacity to serve as soil reinforcement (Duryea \& Dougherty 1991).

\section{Results}

Overall, species survivorship from planted cuttings was $87 \%, 86 \%$, and $73 \%$ after one, 


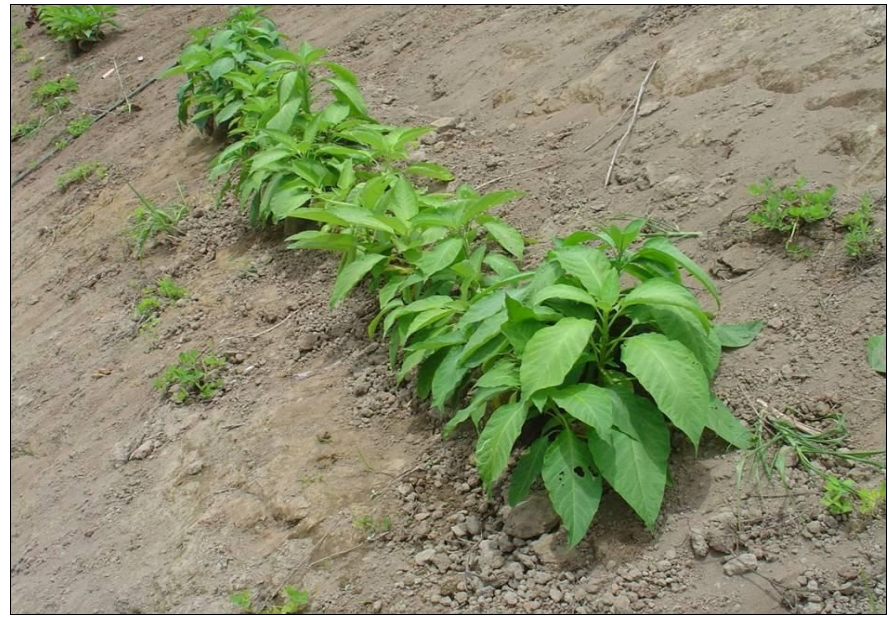

Fig. 5 - Brugmansia versicolor two months after the plantation.

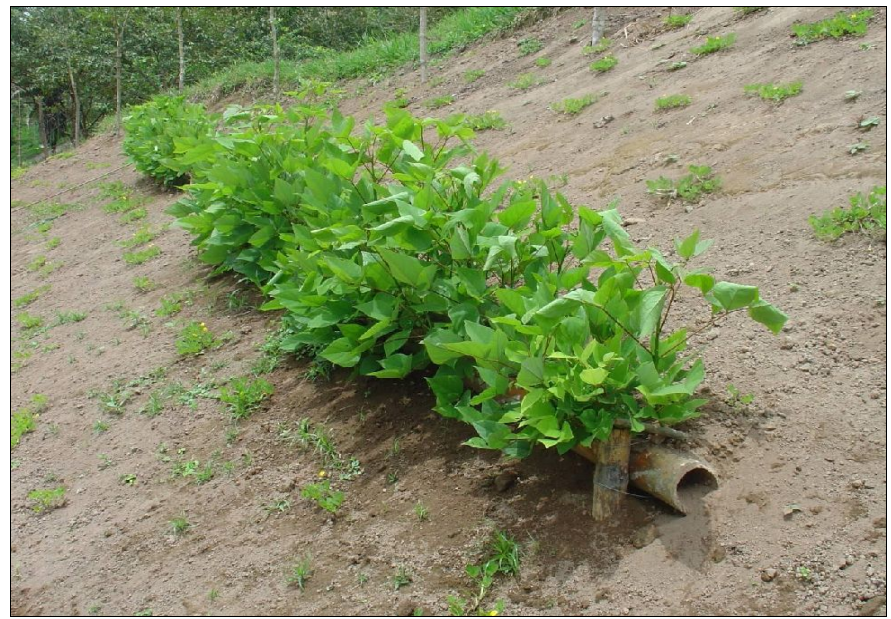

Fig. 7 - Malvaviscus penduliflorus two months after the plantation.

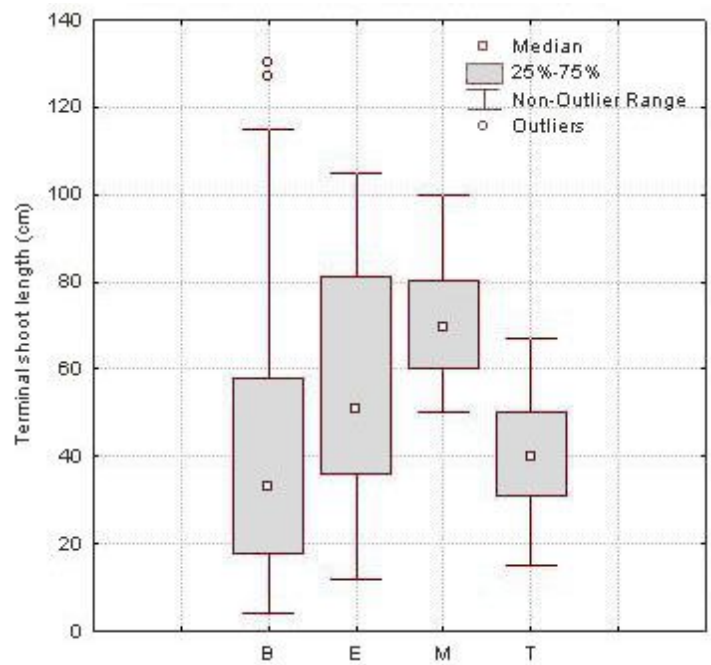

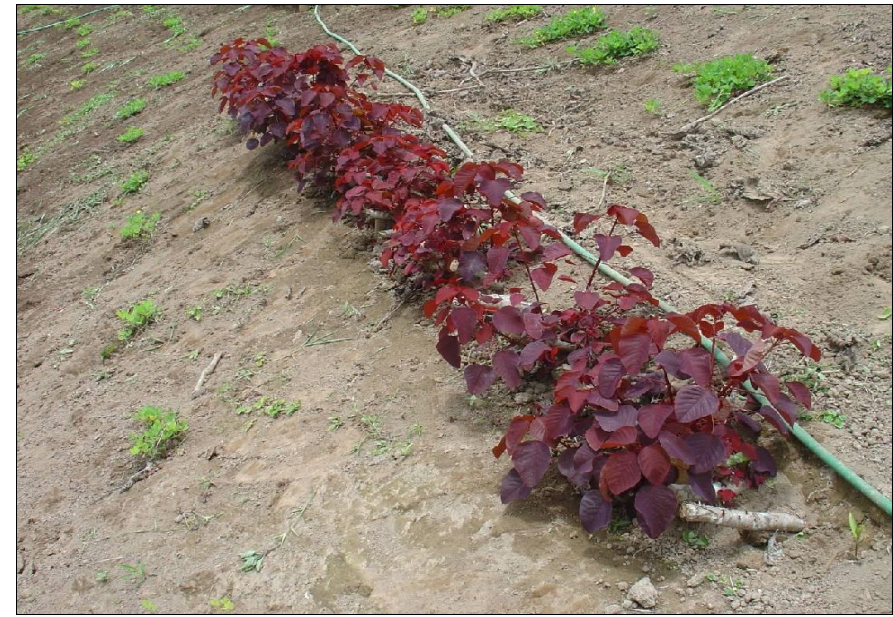

Fig. 6 - Euphorbia cotinifolia two months after the plantation.

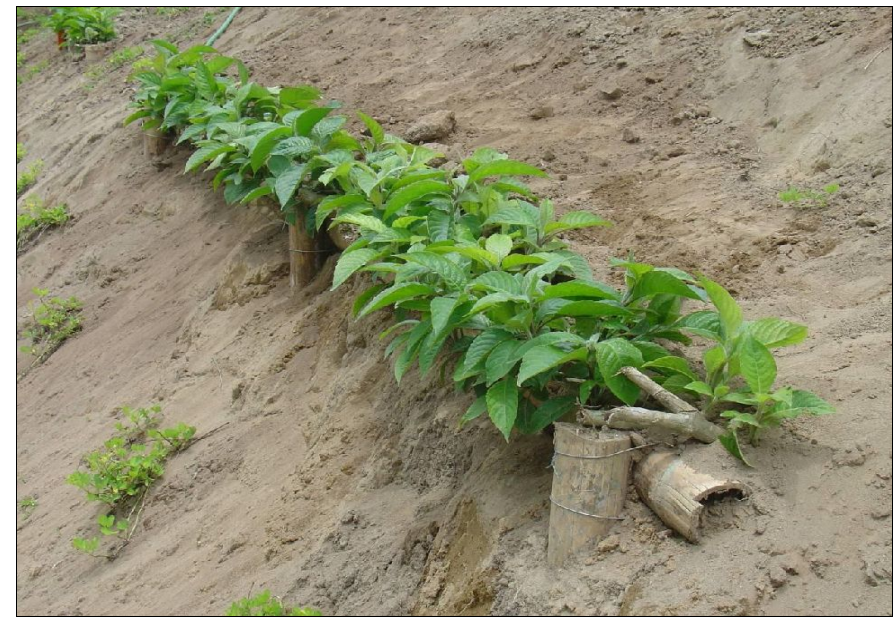

Fig. 8 - Trichanthera gigantea two months after the plantation.

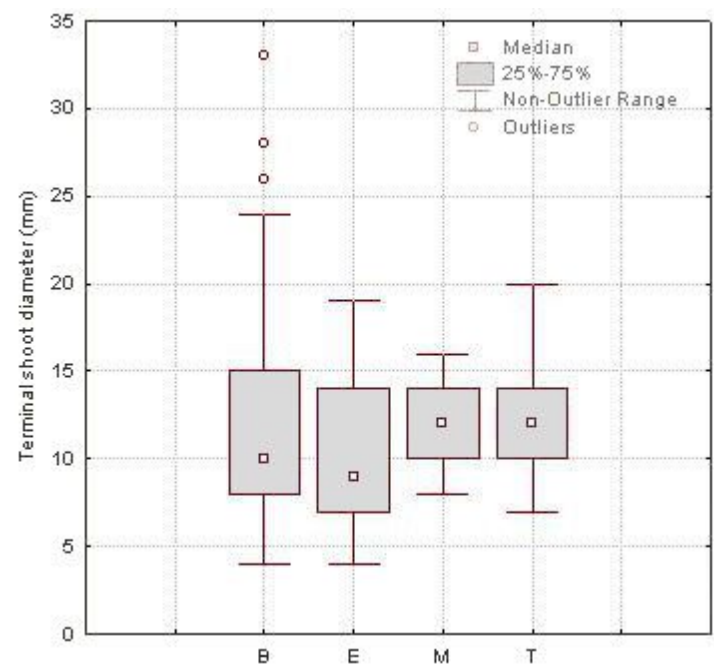

Fig. 9 - Terminal shoot lengths for Brugmansia versicolor (B), Eu- Fig. 10 - Stem diameter at terminal shoot base for Brugmansia verphorbia cotinifolia (E), Malvaviscus penduliflorus (M) and Tri- sicolor (B), Euphorbia cotinifolia (E), Malvaviscus penduliflorus chanthera gigantea $(\mathrm{T}), 5$ months after live palisade construction.
(M) and Trichanthera gigantea (T), 5 months after live palisade construction. 
Tab. 1 - Terminal shoot length and stem diameter at terminal shoot base (mean \pm standard deviation, n=88, 41, 92, and 73 for B. versicolor, E. cotinifolia, M. penduliflorus, and T. gigantea, respectively) five months after palisade construction.

\begin{tabular}{lcccc}
\hline Parameter & B. versicolor & E. cotinifolia & M. penduliflorus & T. gigantea \\
\hline $\begin{array}{l}\text { Terminal shoot } \\
\text { length }\end{array}$ & $40.41 \pm 28.19$ & $58.10 \pm 25.35$ & $71.80 \pm 13.50$ & $40.82 \pm 11.38$ \\
$\begin{array}{l}\text { Stem diameter at } \\
\text { term. shoot base }\end{array}$ & $12.07 \pm 5.87$ & $10.12 \pm 3.83$ & $11.95 \pm 2.20$ & $12.40 \pm 2.75$ \\
\hline
\end{tabular}

two, and five months, respectively. Survival rates after five months for individual species were as follows: B. versicolor, $88 \%$; $E$. cotinifolia, $41 \%$; M. penduliflorus, $92 \%$; and T. gigantea, $73 \%$. Chi-square tests showed a significantly $(P<0.01)$ lower survivorship between $E$. cotinifolia and other species. Overall, B. versicolor, M. penduliflorus, and T. gigantea survivorship performance (survival rate exceeding $70 \%$ ) was more than satisfactory (Lammeraner et al. 2005). E. cotinifolia is naturally distributed on welldrained soils; therefore the low survivorship (41\%) can likely be explained by quite high subsurface water content on the experimental slope.

Average terminal shoot length and stem diameter values are reported in Tab. 1 , and a box plot comparison is given in Fig. 9 and Fig. 10. M. penduliflorus exhibited the highest vegetative performance in shoot length and stem diameter (i.e., greatest shoot length and stem diameter increases). Results indicated notable within-species variability for both traits in $B$. versicolor, which will be investigated in a future trial.

A non-parametric Kruskal-Wallis test was performed, which detected significant differences $(P<0.05)$ among species in terminal shoot lengths. Post-hoc comparisons were subsequently conducted using Least Significant Difference $(L S D)$ criterion. Results showed significant $(P<0.05)$ differences between $B$. versicolor, and E. cotinifolia and $M$. penduliflorus; and between T. gigantea, and E. cotinifolia and M. penduliflorus. Kruskal-Wallis test results also showed significant differences $(P<0.05)$ in shoot diameter among the four species. However, post-hoc LSD comparisons only revealed a significant difference $(P<0.05)$ between $E$. cotinifolia and T. gigantea.

\section{Conclusions}

Our short-term assessment provided a practical assessment of local species suitability for soil bio-engineering work in the Santo Domingo Ecuadorian tropical region. However, it is worth noting that given the large number of biotic and abiotic factors (e.g., soil conditions, drought, competition, slope stability, herbivory, and parasites) that can affect plant viability and vegetative performance over time (Grissinger \& Bowie 1984,
Watson et al. 1997, Preti \& Milanese 2007, Reza Pezeshki et al. 2007), it is highly advisable to plan long-term experiments under different environmental conditions.

\section{Acknowledgements}

This work was funded by the EU project "Reducción de riesgos por desastres en Santo Domingo de los Tsáchilas" (DIPE$\mathrm{CHO}$ ). We acknowledge collaboration with the non-governmental organization CRIC and a Cooperative Agreement with the local institutions. Dr. Carlos Cerón de la Universidad Central del Ecuador and Dr. Paul A. Fryxell of the University of Texas assisted in species identification. We thank also SNGR (National Agency for Risk Management), and the technicians of Santo Domingo and Quito municipalities.

\section{References}

Acharya MS, Lammeranner W (2011). How to select the appropriate techniques and suitable plant species for soil bio-engineering works? An application example from Nepal. Geophysical Research Abstracts, vol. 13, EGU2011-11381, EGU General Assembly.

Duryea ML, Dougherty PM (1991). Forest regeneration manual. Series: Forestry Sciences 36: 440.

Evette A, Labonne S, Rey F, Liebault F, Jancke O, Girel J (2009). History of bio-engineering techniques for rrosion control in rivers in Western Europe. Environmental Management 43: 972984. - doi: 10.1007/s00267-009-9275-y

Florineth F (2004). Stabilization of gullies with soil - bio-engineering methods in the Alps and in Nepal. In: "Gully erosion under global change" (Li Y, Poisen J, Valentin C eds). Sichuan Science and Technology Press, Chengdu, China, pp. 315-339.

Ghimire SK, Karki KK (2004). Mitigation of soil erosion hazards through bio-engineering: a case study of Mid-Himalaya, Nepal. In: Proceedings of the "International Conference Eco-Engineering - The use of vegetation to improve slope stability", Thessaloniki (Greece) 2004.

Gray DH, Sotir RB (1996). Biotechnical and soil bio-engineering slope stabilization. A practical guide for erosion control. John Wiley \& Sons Inc., New York, USA, pp. 378.

Grissinger EH, Bowie AJ (1984). Material and site controls of stream bank vegetation. Transactions of the ASAE 27: 1829-1835.
Lammeraner W, Rauch HP, Laaha G (2005). Implementation and monitoring of soil bio-engineering measures at a landslide in the Middle Mountains of Nepal. Plant Soil 278: 159-170. doi: 10.1007/s11104-005-7012-8

Miner YF, Villagran de Leon JC (2008). Managing landslides in Guatemala, critical issues. In: Proocedings of "The first world landslide Forum". United Nations University (Tokyo, Japan) 18-21 Nov 2008, Session 03, pp. 45-48. Moscatelli M, Romagnoli M, Cenfi S, Lagomarsino A, Di Tizio A, Spina S, Grego S (2009). Wood-soil interactions in soil bioengineering slope stabilization works. iForest 2 (1): 187-191. - doi: 10.3832/ifor0513-002

Osman N, Barakbah SS (2011). The effect of plant succession on slope stability. Ecological Engineering 37 (2): 139-147. - doi: 10.1016/j. ecoleng.2010.08.002

Petley DN, Dunning SA, Rosser NJ (2005). The analysis of global landslide risk through the creation of a database of worldwide landslide fatalities. In: "Landslide risk management" (Hungr O, Fell R, Couture R, Eberhardt E eds). Balkema, Rotterdam,, the Netherlands, pp. 367-374.

Petrone A, Preti F (2005). Ingenieria naturalistica en centroamérica. Manuali tecnici per la cooperazione allo sviluppo. Istituto Agronomico per l'Oltremare, Società Editrice Fiorentina, Firenze, Italy, pp. 108. [in Spanish]

Petrone A, Preti F (2008). Suitability of soil bioengineering techniques in Central America: a case study in Nicaragua. Hydrology and Earth System Sciences 12: 1241-1248. - doi: 10.5194/ hess-12-1241-2008

Petrone A, Preti F (2010). Soil bio-engineering for risk mitigation and environmental restoration in a humid tropical area. Hydrology and Earth System Sciences 14: 239-250. - doi: 10.5194/hess14-239-2010

Preti F, Giadrossich F (2009). Root reinforcement and slope bio-engineering stabilization by Spanish Broom (Spartium junceum L.). HESS 13 (9): 1713-1726.

Preti F, Milanese C (2007). Monitoring ground bio-engineering stabilization of land-slides in Lazio region (Italy). In: Proceedings of the Conference "Eco- and Ground Bio-Engineering: The Use of Vegetation to Improve Slope Stability" (Stokes A, Spanos I, Norris JE, Cammeraat E eds). Thessaloniki (Greece) 13-17 September 2004. Series "Developments in Plant and Soil Sciences", vol. 103. Springer, Dordrecht, The Netherlands, pp. 438.

Preti F, Forzieri G, Chirico GB (2011). Forest cover influence on regional flood frequency assessment in mediterranean catchments. Hydrology and Earth System Sciences 15 (10): 3077 3090. - doi: 10.5194/hess-15-3077-2011

Rauch HP, Rey F, Graf F, Preti F (2011). NH10.4/BG2.18/GM4.4/SSS1.12 - Mitigating against natural hazards: biological contribution to sustainable soil bio-engineering in a changing world. In: Proceedings of the "European Geosciences Union General Assembly 2011". Vienna (Austria) 3-8 Apr 2011. [online] URL: 
http://meetingorganizer.copernicus.org/EGU201 $1 /$ session $/ 7208$

Reubens B, Windey J, Danjon F, Poesen, J, Muys B (2007). Root system architecture of woody species important for erosion control in Tigray, Northern Ethiopia. In: Proceedings of the $4^{\text {th }}$ International Symposium on "Dynamics of Physiological Processes in Roots of Woody Plants" (Lukac M ed). Bangkor (UK) 16-20 Sep 2007. University of Wales, UK. [online] URL: http:// books.google.it/books?id=IrMsAQAAMAAJ

Reza Pezeshki S, Shuwen Li F, Douglas SJr, Lili TM (2007). Factors governing survival of black willow (Salix nigra) cuttings in a streambank restoration project. Ecological Engineering 29: 56-65. - doi: 10.1016/j.ecoleng.2006.07.014
Rivera HR, Sinisterra JA (2006). Uso social de la Bioingeniería para el control de la erosión severa. CIPAV-CVC, Quito, Ecuador.

Rossi Pisa P, Preti F, Rossi M, Ventura F, Mazzanti B (1999). Water, soil and chemical losses: field experiments and model analysis. Water Science and Technology 39 (3): 93-102. doi: 10.1016/S0273-1223(99)00041-4

Schiechtl HM, Michaelsen T (1985). Watershed management field manual: vegetative and soil treatment measures. FAO, Rome, Italy, pp. 61.

Schwarz M, Preti F, Graf F (2006). Effetti stabilizzanti della vegetazione in opere di ingegneria naturalistica - un caso di studio nelle Alpi svizzere. In: Proceedings of the meeting "Le sistemazioni idraulico-forestali per la difesa del ter- ritorio". Saint Vincent (Aosta, Italy) 27 Oct 2006. Nuova Editoriale Bios., Quaderni di Idronomia Montana, vol. 26.

Sutili FJ, Durlo MA, Bressan DA (2004). Biotechnical capability of "sarandi-branco" (Phyllanthus sellowianus mull. Arg.) and "vime", (Salix viminalis $\mathrm{L}$.) for re-vegetation water corse edges. Ciencia Florestal 14 (1): 13-20. [online] URL: http://www.ufsm.br/cienciaflorestal/artigos/v14n1/A3V14N1.pdf

Watson CC, Abt SR, Derrick D (1997). Willow posts bank stabilization. Journal of the American Water Resources Association 33 (2): 293-300. doi: 10.1111/j.1752-1688.1997.tb03510.x 